GEFAD / GUJGEF41(2): 1173-1201(2021)

\title{
Okul Yöneticilerinin Algılanan Yönetim Tarzları ve Öğretmenlerin Özerkliği Üzerine Bir Araştırma*
}

\author{
A Study on Perceived Management Styles of School \\ Administrators and Autonomy of Teachers \\ Püren AKÇAY ${ }^{1}$, Halid Hamza SEVINÇ̧² \\ 'İ́stanbul Aydın Üniversitesi, Eğitim Fakültesi, Eğitim Bilimleri A.B.D. purenakcay@aydin.edu.tr. \\ ${ }^{2}$ Milli Eğitim Bakanlı̆̆ı.halidi0222@gmail.com
}

Makalenin Geliş Tarihi: 31.03 .2021

Yayına Kabul Tarihi: 06.07.2021

\begin{abstract}
$\ddot{O} Z$
$B u$ araştırmanın amacı okul yöneticilerinin sergilemiş olduğu yönetim tarzlarının öğretmen özerkliği ve alt boyutları ile ilişkisini çeşitli değişkenler açısından incelemektir. İlişkisel tarama modeline göre desenlenen bu araştırmada veri toplama aracı olarak 'Öğretmen Özerklik Ölçeği', ve "Algılanan Müdür Yönetim Tarzı Ölçeği”’ kullanılmıştır. Araştırmanın örneklemini, amaçlı örnekleme yöntemlerinden rastgele örnekleme yöntemi ile belirlenen ve 2020-2021 eğitim öğretim yılında Adıyaman ili Kahta ilçesindeki ilkokullarda görev yapmakta olan 367 öğretmen oluşturmaktadır. Araştırma bulgularından elde edilen sonuçlara göre okul yöneticilerinin yönetim tarzlarında en yüksek puan ortalamasının işbirlikli yönetim tarzına, en düşük puan ortalamasının ise ilgisiz yönetim tarzına ilişkin olduğu görülmektedir. Öğretmenlerin sınıf içindeki özerklik düzeylerinde, ögrretim sürecinde öğretmenin özerkliği ile işbirlikli yönetim tarzı arasında pozitif yönlü, düşük düzeyde çift yönlü, anlamlı ilişki bulunması araştırmadan elde dilen bir diğer sonuçtur.
\end{abstract}

Anahtar Sözcükler: Okul yönetimi, Öğretmen özerkliği, Yönetim tarzı.

\section{ABSTRACT}

The aim of this study is to examine the relationship between school administrators' management styles and teacher autonomy and its sub-dimensions in terms of various variables. "Teacher Autonomy Scale" and "Perceived Principal Management Style Scale" were used as data collection tools in this study, which was designed according to the relational screening model.

\footnotetext{
* Alıntılama: Akçay, P. Sevinç, H.H. (2021). Okul Yöneticilerinin Algılanan Yönetim Tarzları ve Öğretmenlerin Özerkliği Üzerine Bir Araştırma. Gazi Üniversitesi Gazi Eğitim Fakültesi Dergisi, 41(2), 1173-1201.
} 
The sample of the study consists of 367 teachers who are determined by random sampling method, one of the purposeful sampling methods, and working in primary schools in Kahta district of Adiyaman in the academic year of 2020-2021. According to the results obtained from the research findings, it is seen that the highest score average of school administrators' management style is related to the cooperative management style, and the lowest average score is related to the irrelevant management style. Another result of the study is that there is a positive, low level, two-way, significant relationship between the autonomy of teachers in the classroom and the teacher's autonomy in the teaching process and the cooperative management style.

Keywords: School management, Teacher autonomy. Management style.

\section{GíRiş}

Örgütün hedefleri doğrultusunda verimli ve etkin kullanılan üretim faktörlerinden yönetim sürecine işlerlik kazandıran en önemli faktör insan unsurudur. Yönetim, belirli birtakım amaçlara ulaşmak için başta insanlar olmak üzere parasal kaynakları, donanımı, demirbaşları, hammaddeleri, yardımcı malzemeleri ve zamanı birbiriyle uyumlu, verimli ve etkin kullanabilecek karar alma ve uygulatma süreçlerinin toplamıdır (Eren, 2011). Yönetim tarzı ise, yöneticinin yetkiyi kullanış şekli ve yöneticilerin örgütü hedeflerine ulaştırmakta kullandıkları yöntem olarak ifade edilir (Akçay, 2020). Yöneticinin nasıl bir yönetim tarzı uygulayacağı, sahip olduğu değerlerle yakından ilgilidir (Akçay, 2020). Yöneticiler görevlerini yaparken yetiştikleri kültürün etkisinden, ön yargılarından ve tutucu olmaktan ne kadar arınırsa o oranda başarılı olur. Yönetim tarzı, her yöneticiye özgüdür. Başaran'a (2000) göre yönetsel yetkinin kullanılış şekli kişiden kişiye farklılık gösterebilir. Yönetsel yetkinin kullanılış tarzı da yönetim tarzını etkileyen unsurlardandır.

Okul etkililiğini artıracak bir okul kültürünün geliştirebilmesi için, okul yöneticisi bu doğrultuda bir yönetim tarzı belirlemelidir. Okul iklimi ve kültürünün sağlıklı, olumlu olması okul yöneticilerinin ortaya koyacağı liderlik stili ile yakından ilgilidir (Açıkalın, 2000). Bu anlamda okul yöneticileri uygun yönetim tarzını sergileyerek öğretmenlere özerklik sağlamalı, öğretmenleri yönetim ve karar alma süreçlerine dâhil etmelidir. Öğretmenlerin, öğretimsel faaliyetlerinin geliştirilmesi ve verimliliğinin artırılmasına 
yönelik uygulamalarda bulunmaları, yeni ve farklı öğretim yöntem ve materyalleri kullanmaları, mesleki becerilerini artırmaları için öğretmenlere sistem içinde daha çok özerklik tanınmalıdır (Üzüm ve Karslı, 2013).

Yönetim tarzlarının ortaya çıkmasının sebebi yöneticilerin bireysel farklılıklarıdır. Başaran'a (2000) göre yönetsel yetkinin kullanılış şekli kişiden kişiye farklılık gösterebilir. Yöneticilerin sergileyeceği davranışlar çalışanları olumlu veya olumsuz yönde etkileyebilmektedir. Yönetmenin şeklini ve çeşidini belirleyen en önemli unsur yöneticinin yetki ve sorumluluklarını yerine getirme tarzıdır (Terzi ve Kurt, 2005). Çalışanlarda güven ve motivasyonu artıracak bir yönetim tarzı başarı ve verimliliği artırmaktadır. $\mathrm{Bu}$ araştırmada temel alınan gruplandırmada, okul yöneticilerini sergilemiş olduğu yönetim tarzları işbirlikli, otoriter, ilgisiz ve karşı koyucu yönetim tarzıdır (Üstüner, 2016).

Robins, vd. (2013), araştırmalarında bu 4 yönetim tarzını tanımlamışlardır. Buna göre, işbirlikli yönetim tarzında okul yöneticisi okulu tek başına yönetmek yerine tüm çalışanları yönetim ve karar alma süreçlerine katarak yetki ve görev paylaşımında bulunmaktadır. İşbirlikli okul yönetim tarzı, okul iklimini ve okul etkililiğini olumlu yönde etkileyen bir durumdur (Çelik, 2012). Kürkçü (2019) de okulların işgörenler arasında işbirlikçi ve demokratik ilişkilerin kurulduğu yapılar olduğunu belirtmektedir. Okul müdürlerinin işbirlikçi öğrenme ortamlarını sağlaması ve mesleki gelişimi destekleyici uygulamalar yapması öğretmenlerin özerklik düzeyini arttırmaktadır (Garvin, 2007). Otoriter yönetim tarzı, çalışanlar arasında statü ve yetki farklılığının yanında çalışanlar arasındaki ekonomik ve sosyal hakların da farklı olduğu tek kişi yönetim anlayışına dayalı bir yönetim tarzıdır. Otorite yönetim insan ve süreç faktöründen daha çok ürün odaklı bir anlayışa dayanır (Robbins, vd., 2013). İlgisiz yönetim tarzı, örgüt yöneticilerinin yönetim faaliyetlerinde yetkilerini astlarına devretmesi, çalışanlara yönlendirme noktasında bir müdahalede bulunmaması gibi davranışlarının tümü olarak açıklanmaktadır (Robbins, vd., 2013). İlgisiz yönetim tarzı, çalışanların serbestçe işlerini yapmaları anlayışına dayanır. Karşı koyucu yönetim tarzı ise örgütlerde yöneticilerin, hedef ve amaçları gerçekleştirilmesinde çalışanları 
yönlendirerek veya engelleyerek süreci yönetmeleridir (Robbins, vd., 2013). Karş1 koyucu yönetim tarzında yöneticilerin gereğinden fazla gösterdikleri şüpheci ve güvensiz davranışlar hedef ve amaçların gerçekleşmesinde büyük engel teşkil etmektedir (Üstüner, 2016).

Okul yöneticilerinin yönetim tarzlarının öğretmenlerin özerklik alanlarında değişiklik yaratılabileceği düşünülmektedir. Özerklik, bir üst merciye bağlı olarak, kendini yönetme yetkisinin özel kanunlarla belirlendiği yapı ve yönetim açısından diş denetimden bağımsız olma durumudur (Üzüm, 2014). Öğretmen özerkliği kavramı öğretmenlerin görevlerini yerine getirirken sahip oldukları özgürlük alanını tanımlamaktadır. Öğretmen özerkliği bir öğretmen için bilgi, beceri ve davranışta yeterlilik ve yasal olarak mesleğini icra edebilmesi için karar ve sorumluluk alma yetkisine sahip olmasıdır. Öğretmen özerkliği öğretmenlerin kendilerini ve iş çevrelerini kontrol edebilme hissine sahip olmasıdır (Üzüm, 2014; Üzüm ve Karslı, 2013). Öğretmen özerkliği öğretim programı, kullanılacak öğretim yöntem ve teknikleri, öğrenci başarısı ve davranışını ölçme ve değerlendirme işlemleri, öğrenci disiplini, sınıf ortamı ve etkinlikler için harcanacak zamanın düzenlenmesi ve öğretmenin kendi mesleki gelişimi üzerinde doğrudan etkilidir.

Öğretmen özerkliğinin boyutları öğretimsel, yönetsel, mali, kişisel ve mesleki özerklik olarak sıralanabilir. Öğretimsel özerklik sınıf içi öğretim uygulamaları ile ilgili boyuttur. Öğretmenlerin okuldaki rolleri çok çeşitli olsa da temel görevleri öğrenenlerin eğitim ve öğretim faaliyetlerinin planlanması ve gerçekleştirilmesidir (Üzüm, 2014). Eğitim sırasında öğretmenlerin sınıf içinde diledikleri öğretim yöntem ve tekniği kullanabilmesi, öğretim ortamını düzenlemesi öğretimsel özerklikle ilgilidir. Öğretmen özerkliğinin öğretimsel boyutuna ilişkin alanyazında çeşitli araştırmalar mevcuttur (Çelikkaya ve Kuş, 2009; Demir ve Özden, 2013; Doğru ve Aydoğdu, 2003; Friedman, 1999; Karasu ve Avc1, 2019). Yönetsel özerklik, öğretmenlerin mali, insan ve diğer kaynak kullanımında ve bu kaynakların yönetiminde karar verme yetkisine sahip olması, eğitimle ilgili alınan kararlarda söz sahibi olmasıdır. Mali özerklik okulların merkezi yönetimden bağımsız olarak kendi mali kaynaklarına sahip olması durumuyla 
ilişkilidir (Gürsoy, 2020). Mali özerklik, öğretmenlerin maddi ve insan kaynaklarının nasıl kullanılacağı ile ilgili yapılacak planlama ve uygulama süreçlerine dâhil edilmesi ve söz sahibi olmasıdır. Kişisel ve mesleki özerklik ise öğretmenlerin, eğitim ve öğretim faaliyetlerinin iyileştirmesi için gayret göstermeleri, güncel öğretim yöntemlerini takip etmeleri, yeni eğitim öğretim materyalleri geliştirmeleri ve mesleki bilgi ve becerilerini iyileştirmeleri olarak görülmektedir. Öğretmenlerin karar alma ve bu kararları uygulama yetkilerinin sınırlarını belirleyen önemli unsurlardan biri de öğretmenlerin özerklik düzeyidir (Üzüm,2014). Öğretmenlerin bürokratik yapıya ilişkin algılarının, görev yaptıkları okul müdürlerinin sergilediği yönetim tarzına ilişkin algıları ile ilişkili olduğu ve bu ilişkinin belirlenmesinin önemli olduğu düşünülmektedir (Alanoğlu ve Demirtaş, 2019).

Yönetim tarzı ve öğretmen özerkliğine ilişkin belirtilenler dikkate alındığında okul yöneticisinin yönetim tarzının okul etkililiğini artıracak şekilde belirlemesi ve bu yönetim tarzında eğitim öğretim sürecinde öğretmenlerin verimini arttırmak için öğretmenlere daha fazla özerklik alanı sağlayan yönetsel eylemlere yönelmesi gerekliliği araştırmanın problemini oluşturmaktadır. Bu araştırma okul yöneticilerinin algılanan yönetim tarzlarını belirlemenin yanında öğretmenlerin sınıf içinde öğretim sürecinde sahip oldukları ve eğitim sisteminin genelinde sahip oldukları özerklik düzeyinin belirlenmesine de katkı sağlayacaktır. Bunlara ek olarak öğretmenlerin hangi konularda hak sahibi olduğunu ve hangi konularda hak sahibi olması gerektiğine ve öğretmen özerkliği uygulama şekillerinin hangi kriterlere göre belirlenmesine ilişkin öğretmen görüşleri, öğretmenlerin özerklik alanlarının sınırlarının yeniden belirlenmesinde önem arz etmektedir. Öğretmenlerin özerkliğinin gerek sınıf içinde gerek okul yönetiminde ve gerek eğitim sisteminde artırılması da öğretmenlerin motivasyonlarını, verimliliklerini ve örgütsel bağlılıklarını artıracağı düşünülmektedir.

\section{Araştırmanın Amacı}

Yapılan kuramsal açıklamaların çerçevesinde bu araştırmanın amacı, okul yöneticilerinin yönetim tarzları ile öğretmen özerkliği arasındaki ilişkiyi çeşitli 
değişkenler çerçevesinde ortaya koymaktır. Bu temel amaç doğrultusunda bu araştırmada şu sorulara yanıt aranmıştır:

1. Okul yöneticilerinin algılanan yönetim tarzları ve öğretmenlerin özerklikleri ne düzeydedir?

2. Okul yöneticilerinin algılanan yönetim tarzları ve öğretmenlerin özerklik düzeyleri cinsiyet, yaş, kıdem, eğitim düzeyi, yöneticilik deneyimi, branş ve okul türü değişkenine göre anlamlı farklılık göstermekte midir?

3. Okul yöneticilerinin algılanan yönetim tarzları ile öğretmenlerin özerklik düzeyleri arasında ilişki var mıdır?

\section{YÖNTEM}

Yöntem bölümünde araştırmanın modeli, evren ve örneklemi, veri toplama araçları ile verilerin analizi ile ilgili bilgiler yer almaktadır.

\section{Araştırma Modeli}

$\mathrm{Bu}$ araştırma nicel araştırma yöntemlerinden ilişkisel tarama modeli kullanılmıştır. İlişkisel tarama yöntemi, iki ya da daha fazla değişkeni inceleyerek bu değişkenlerin beraberce değişip değişmediğini, değişme yaşanıyorsa bunun ne şekilde olduğunu bulmayı hedefleyen bir yöntemdir (Büyüköztürk, 2012).

\section{Evren ve Örneklem}

Araştırmanın evrenini, Adıyaman ili, Kâhta ilçesindeki görevli sınıf öğretmenleri oluşturmaktadır. Araştırmanın örneklemi ise, Adıyaman ili, Kâhta ilçesinde yer alan devlet ilkokullarında görev yapmakta olan 367 sınıf öğretmeninden oluşmaktadır. Örneklem seçilirken her bir örnekleme birimine eşit seçilme ihtimalinin verilmesiyle (seçilen birimin yerine konulmasıyla) seçilen birimlerin örnekleme alınması olarak tanımlanan basit tesadüfî örnekleme (Başaran, 2017) yöntemi kullanılmıştır. Adıyaman ili Kâhta ilçesinde yer alan 91 ilkokulda görev yapan 625 sınıf öğretmeninden 412'sine ulaşılmış, ulaşılan öğretmenlerin 367'si araştırmaya katılmayı kabul etmiştir. 


\section{Veri Toplama Araçları}

$\mathrm{Bu}$ araştırmada, veri toplama aracı olarak 'Sosyo-demografik Bilgi Formu', 'Algılanan Müdür Yönetim Tarzı Ölçeği’ ve ‘Öğretmen Özerkliği Ölçeği’ kullanılmıştır.

Öğretmen Özerkliği Ölçeği: Araştırma alt amaçlarından öğretmen özerklik düzeyini belirlemede Üzüm ve Karslı (2013) tarafından geliştirilen ölçek 4 boyut ve 43 maddeden oluşan 'Öğretmen Özerkliği Ölçeği’ kullanılmıştır. Ölçeğin birinci boyutu 'Öğretim Sürecinde Özerklik', ikinci boyutu 'Eğitim sisteminde özerklik', üçüncü boyutu 'Öğretmenlerin hak ve sorumluluk düzeyi', dördüncü boyutu ise 'Öğretmen Özerklik Uygulamaları’ olarak şekillenmektedir. Öğretmen Özerkliği ölçeği (1) Hiç, (2) Az, (3) Orta, (4) Çok, (5) Tamamen şeklinde derecelendirilmiş 5'li likert tipi bir ölçektir. Üzüm ve Karslı'nın (2013) yaptığı çalışmada hesaplanan '’Öğretmen Özerklik Ölçeği”, Cronbach Alpha iç tutarlık katsayıları, 'Öğretim Sürecinde Özerklik' için 0.93, 'Eğitim Sisteminde Özerklik', için 0.93, 'Öğretmenlerin Hak ve Sorumluluk Düzeyi" için 0.95 ve "Öğretmen Özerklik Uygulamaları' için 0.76 olarak hesaplanmıştır. Mevcut çalışmada ise iç tutarlılık katsayısı 'Öğretim Sürecinde Özerklik' için 0.90, 'Eğitim Sisteminde Özerklik', için 0.88, Hak ve Sorumluluklar Düzeyi', için 0.96 ve 'Öğretmen Özerklik Uygulamaları', için 0.85 olarak hesaplanmıştır. Öğretmen özerkliği ölçeği Alpha Cronbach’s güvenirlik katsayısı ise 0,93 olarak hesaplanmıştır. Ölçekten elde edilen cronbach alpha güvenirlik katsayısı, ölçeğin öğretmenlerin özerklik düzeyini ölçmede güvenilir bir araç olduğunu göstermektedir.

Algılanan Müdür Yönetim Tarzı Ölçeği: Üstüner (2016) tarafindan geliştirilen ‘Algılanan Müdür Yönetim Tarzı Ölçeği'nin (A-MYTÖ) geliştirilmesi sürecinde öncelikle ölçeğin kapsam geçerliği sağlanmaya çalışılmıştır. Üstüner (2016) tarafından geliştirilen bu ölçek 4 boyut ve 25 maddeden oluşmaktadır. Ölçek işbirlikli, otoriter, ilgisiz ve karşı koyucu yönetim tarzı olmak üzere dört alt boyuttan oluşmaktadır. Ölçek 5'li Likert tipinde hazırlanmış, sıralama her zaman'dan (5) hiçbir zaman'a (1) doğru yapılmıştır. Üstüner'in (2016) çalışmasında hesaplanan “'Algılanan Müdür Yönetim Tarzı Ölçeği”, Cronbach Alpha iç tutarlık katsayıları, "İşbirlikli Yönetim Tarzı” alt 
boyutu için 0.92, "Otoriter Yönetim Tarzı" alt boyutu için 0.89, "İlgisiz Yönetim Tarzı" alt boyutu için 0.86 ve "Karşı Koyucu Yönetim Tarzı" alt boyutu için 0.85 şeklindedir. Cronbach Alpha güvenirlik katsayısı ise 0.89 olarak hesaplanmıştır. Mevcut çalışmada ise iç tutarlılık katsayısı "İşbirlikli Yönetim Tarzı" için 0.95, "Otoriter Yönetim Tarzı" için 0.89, "Illgisiz Yönetim Tarzı" için 0.92 ve "Karşı Koyucu Yönetim Tarzı" için ise 0.92 olarak hesaplanmıştır. "Algılanan Müdür Yönetim Tarzı Ölçeğì" cronbach’s alpha güvenirlik katsayısı ise 0,88 olarak hesaplanmıştır. Ölçekten elde edilen cronbach's alpha güvenirlik katsayısı, ölçeğin öğretmenlerin özerklik düzeyini ölçmede güvenilir bir araç olduğunu göstermektedir.

\section{Verilerin Analizi}

Veri toplama araçları ile katılımcılardan toplanan veriler SPSS 25 istatistik analiz programı aracılığıyla analiz edilmiştir. Araştırmada kullanılan ölçeklerin güvenirlikleri cronbach's alpha katsayısı yardımıyla ölçülmüştür. Yönetim becerileri ölçeği ve mizah davranışları ölçeğinin tüm alt boyutlarında ve her iki ölçeğin de bütününde güvenirlik yüksek derecede bulunmuştur. Verilerin normal dağılımının kontrolü için, basıklık ve çarpıklık değerleri esas alınmıştır. Bu veriler dikkat alındığında dağı̆ımın normallik gösterdiği kabul edilerek Öğretmen Özerkliği Ölçeği ve Algılanan Müdür Yönetim Tarzı Ölçeklerinden elde edilen verilerin analizinde parametrik testlerin uygulanmasına karar verilmiştir. Araştırmada kullanılacak her iki ölçeğe ilişkin veriler normal dağılım gösterdiği için (Demir, Saatçioğlu ve İmrol, 2016), betimleyici istatistiklerden aritmetik ortalama ve standart sapma değerleri dikkate alınmış, verilerin analizinde ise iki grubu bulunan değişkenlere Bağımsız T Testi, üç ya da daha fazla gruplu değişkenlere Tek Yönlü Varyans Analizi (ANOVA) uygulanmıştır. Son olarak okul müdürlerinin yönetim tarzları ve öğretmen özerklik düzeyleri arasındaki ilişki düzeyinin belirlenmesinde pearson korelasyon analizinden istifade edilmiştir. Yapılan analizlerde anlamlılık düzeyi $\mathrm{p}<.05$ olarak değerlendirmeler yapılmıştır. 


\section{Etik Kurallara Uygunluk}

Araştırmanın verileri, İlçe Milli Eğitim Müdürlüğü’nden gerekli izinler alındıktan sonra katılımcılardan yüz yüze ve e posta aracılığı ile elde edilmiştir. Söz konusu çalışma için gerekli etik kurul incelemesi, İstanbul Aydın Üniversitesi Etik Kurul'u tarafindan yapılarak, 03.03.2021 tarih, 2021/02 sayılı kararı ve E-88083623-020-7798 evrak numarası ile uygun bulunmuştur. Bu açıklamaya ek olarak İstanbul Aydın Üniversitesi Etik Kurul onay evrakı Ek-1'de sunulmuştur.

\section{BULGULAR}

Bulgular ve bulgulara ait yorumlar, araştırma sorularının verilişindeki sıraya uygun olarak tablolaştırılıp düzenlenmiştir.

\section{Yönetim Tarzlarına ve Öğretmen Özerkliğine İlişkin Bulgular}

Araștırmaya katılan öğretmenlerin algılanan müdür yönetim tarzlarına ve özerklik düzeylerine ilişkin betimsel analiz sonuçları Tablo 1'de gösterilmiştir.

Tablo 1. Yönetim Tarzları ve Öğretmen Özerkliğine İlişkin Betimsel Analiz Sonuçları

\begin{tabular}{lccccc}
\hline \multicolumn{1}{c}{ Ölçekler ve Boyutları } & $\mathrm{n}$ & Minimum & Maksimum & $\overline{\mathrm{x}}$ & $\mathrm{SS}$ \\
\hline Öğretmen Özerkliği Ölçeği & 367 & 2.51 & 5.00 & 4.23 & .50 \\
Öğretim sürecinde özerklik & 367 & 3.00 & 5.00 & 4.58 & .46 \\
Hak sahibi olmalıdır & 367 & 2.82 & 5.00 & 4.59 & .45 \\
Hak sahibidir & 367 & 1.00 & 5.00 & 4.05 & .94 \\
Öğretmen Ö. kriterleri & 367 & 1.22 & 5.00 & 3.69 & .89 \\
\hline Yönetim Tarzı Ölçeği & 367 & 1.75 & 5.00 & 2.74 & .66 \\
İşbirlikli Yönetim & 367 & 1.00 & 5.00 & 4.15 & .92 \\
Otoriter Yönetim & 367 & 1.00 & 5.00 & 2.76 & 1.05 \\
İlgisiz Yönetim & 367 & 1.00 & 5.00 & 2.00 & 1.03 \\
Karşı Koyucu Yönetim & 367 & 1.00 & 5.00 & 2.05 & 1.14 \\
\hline
\end{tabular}

Tablo 1'deki okul yöneticilerinin algılanan yönetim tarzları ölçeğinin puan ortalamaları incelendiğinde, en yüksek puan ortalamasının işbirlikli yönetim tarzına ( $\overline{\mathrm{x}}=4.15)$ ve en düşük puan ortalamasının ise ilgisiz yönetim tarzına $(\overline{\mathrm{x}}=2.00)$ ilişkin olduğu görülmektedir. Öğretmenlerin okul yöneticilerinin yönetim tarzlarını işbirlikli olarak algılanması okul iklimini ve dolayısıyla okul etkililiğini olumlu yönde etkileyen bir 
durumdur. Günümüz okulları, işgörenler arasında işbirlikçi ve demokratik ilişkilerin kurulduğu yapılardır (Kürkçü, 2019). Destekleyici liderlik kapsamında okul müdürlerinin işbirlikçi öğrenme ortamlarını sağlaması ve mesleki gelişimi destekleyici uygulamalar yapması öğretmenlerin özerklik düzeyini arttırmaktadır (Garvin, 2007). Öğretmen özerkliği ölçeği değerleri incelenirken araştırmanın amacı çerçevesinde öğretmen özerkliği ölçeği maddelerinin ayrı ayrı ortalamalarının yorumlanması daha uygun görülmüştür. Bu doğrultuda Tablo 2'de öğretmen özerkliği ölçeği maddelerine ilişkin betimsel analiz sonuçları verilmektedir.

Tablo 2. Öğretmen Özerkliği Ölçeği Betimsel Analiz Sonuçları

\begin{tabular}{|c|c|c|c|c|}
\hline Öğretmen Özerkliği Ölçeği Maddeleri (n=367) & Min. & Maks. & $\overline{\mathrm{x}}$ & SS \\
\hline \multicolumn{5}{|l|}{ Öğretim sürecinde özerklik } \\
\hline 1.Öğretimin amaç ve hedeflerini belirleme & 1.0 & 5.0 & 4.53 & .71 \\
\hline 2.Sınıfta öğretimin içeriğini belirleme & 1.0 & 5.0 & 4.59 & .64 \\
\hline 3.Öğretim yöntem ve stratejilerini belirleme & 2.0 & 5.0 & 4.62 & .62 \\
\hline 4.Öğretim yaklaşımlarında yaratıcı değişiklikler yapma & 1.0 & 5.0 & 4.56 & .63 \\
\hline 5.Öğretim etkinliklerinde farklı yöntemler kullanma & 3.0 & 5.0 & 4.67 & .55 \\
\hline 6.Öğretim materyallerinin seçme & 1.0 & 5.0 & 4.64 & .60 \\
\hline 7.Ölçme ve değerlendirme yöntemlerinin seçme & 1.0 & 5.0 & 4.58 & .62 \\
\hline 8.Sınıftaki fiziksel alanın kullanıma & 3.0 & 5.0 & 4.66 & .56 \\
\hline 9.Sınıftaki öğretim zamanlarını belirleme & 1.0 & 5.0 & 4.44 & .75 \\
\hline 10.Sınıftaki davranış kurallarını belirleme & 1.0 & 5.0 & 4.57 & .66 \\
\hline 11.Öğrenci özerkliğini destekleme & 2.0 & 5.0 & 4.54 & .69 \\
\hline \multicolumn{5}{|l|}{ Öğretmen hak sahibi olmalıdır } \\
\hline 12.Sınıfta öğretim sürecini istediğim şekilde yönetmek & 1.0 & 5.0 & 4.57 & .70 \\
\hline 13.Öğretim sürecinde istediğim değişiklikleri yapabilmek & 1.0 & 5.0 & 4.51 & .72 \\
\hline 14.Ölçme değerlendirme yöntemlerini değiştirebilmek & 1.0 & 5.0 & 4.59 & .65 \\
\hline $\begin{array}{l}\text { 15.Sınıf içi öğretim zamanlarında değişiklikler } \\
\text { yapabilmek }\end{array}$ & 1.0 & 5.0 & 4.56 & .68 \\
\hline 16.Mesleki yeterliliğimi geliştirmek & 2.0 & 5.0 & 4.72 & .50 \\
\hline 17.Öğretim sorunlarının çözümüne katılmak & 2.0 & 5.0 & 4.68 & .54 \\
\hline 18.Öğretmenlik mesleği ile ilgili kararlara katılabilmek & 1.0 & 5.0 & 4.66 & .60 \\
\hline 19.Mesleki geleceğim ile ilgili kararlar alabilmek & 1.0 & 5.0 & 4.72 & .56 \\
\hline 20.Okulda yönetim süreçlerine katılmak & 1.0 & 5.0 & 4.35 & .89 \\
\hline $\begin{array}{l}\text { 21.Mesleğimle ilgili istediğim konularda araştırma } \\
\text { yapmak }\end{array}$ & 1.0 & 5.0 & 4.74 & .52 \\
\hline 22.Topluma liderlik yapmak & 2.0 & 5.0 & 4.43 & .78 \\
\hline \multicolumn{5}{|l|}{ Öğretmen hak sahibidir } \\
\hline 23.Öğretim sorunlarının çözümünde & 1.0 & 5.0 & 4.04 & 1.15 \\
\hline 24.Eğitim programlarının geliştirilmesinde & 1.0 & 5.0 & 3.80 & 1.31 \\
\hline
\end{tabular}




\begin{tabular}{|c|c|c|c|c|}
\hline 25.Öğretmenlik mesleği ile ilgili kararların alınmasında & 1.0 & 5.0 & 3.81 & 1.39 \\
\hline 26.Geleceğimle ilgili mesleki karalar alabilmede & 1.0 & 5.0 & 4.07 & 1.19 \\
\hline 27.Eğitimin okul düzeyindeki kararların alınmasında & 1.0 & 5.0 & 4.00 & 1.12 \\
\hline 28.Okulda yönetim süreçlerine katılmada & 1.0 & 5.0 & 3.94 & 1.12 \\
\hline $\begin{array}{l}\text { 29.Çalışma ortamının düzeni ile ilgili kararların } \\
\text { alınmasında }\end{array}$ & 1.0 & 5.0 & 4.11 & 1.06 \\
\hline 30.Mesleki konularsa bilimsel araştırma yapmada & 1.0 & 5.0 & 4.09 & 1.10 \\
\hline 31.Diğer çeşitli konularda araştırma yapmada & 1,0 & 5,0 & 4,06 & 1,07 \\
\hline 32.Meslektaşlarımla iletişim halinde olmada & 1,0 & 5,0 & 4,42 &, 81 \\
\hline 33.Meslektaşlarımla bağlılık ilişkisi kurmada & 1,0 & 5,0 & 4,34 & ,86 \\
\hline 34.Topluma liderlik yapmada & 1.0 & 5.0 & 3.96 & 1.10 \\
\hline \multicolumn{5}{|l|}{ Öğretmen Özerkliği Kriterleri } \\
\hline $\begin{array}{l}\text { 35. Öğretmenlerin özerklik düzeyini okul yönetimi } \\
\text { belirlemelidir }\end{array}$ & 1.0 & 5.0 & 3.14 & 1.50 \\
\hline $\begin{array}{l}\text { 36. Öğretmenlerin özerklik düzeyi toplum tarafından } \\
\text { belirlemelidir }\end{array}$ & 1.0 & 5.0 & 2.99 & 1.58 \\
\hline $\begin{array}{l}\text { 37. Öğretmenlerin özerklik düzeyini merkezi yönetimin } \\
\text { belirlemelidir }\end{array}$ & 1,0 & 5,0 & 3,14 & 1,50 \\
\hline $\begin{array}{l}\text { 38. Öğretmenlerin özerklik düzeyi öğretmenin eğitim } \\
\text { düzeyine göre belirlenmelidir }\end{array}$ & 1.0 & 5.0 & 3.87 & 1.20 \\
\hline $\begin{array}{l}\text { 39. Öğretmenlerin özerklik düzeyini öğretmenin mesleki } \\
\text { deneyimine göre belirlemelidir }\end{array}$ & 1.0 & 5.0 & 4.07 & 1.08 \\
\hline $\begin{array}{l}\text { 40.Öğretmenler mesleklerinde sorumlulukları oranında } \\
\text { yetkiye sahip değildirler }\end{array}$ & 1.0 & 5.0 & 3.96 & 1.20 \\
\hline $\begin{array}{l}\text { 41.Öğretmenler öğrenciler üzerinde sahip oldukları önem } \\
\text { oranında yetkiye sahip değildirler }\end{array}$ & 1.0 & 5.0 & 3.95 & 1.18 \\
\hline $\begin{array}{l}\text { 42.Öğretmenler toplum üzerinde sorumlulukları oranında } \\
\text { yetkiye sahip değildirler }\end{array}$ & 1.0 & 5.0 & 3.96 & 1.19 \\
\hline $\begin{array}{l}\text { 43.Katı merkezi yönetim öğretmen özerkliğine engel } \\
\text { olmaktadır }\end{array}$ & 1.0 & 5.0 & 4.09 & 1.12 \\
\hline
\end{tabular}

Tablo 2'ye göre, öğretmenlerin sınıf içindeki özerklik düzeylerinde öğretim sürecinde farklı yöntemler kullanma hususunda en yüksek düzeyde $(\bar{x}=4.67)$ özerk olmaları gerektiğini düşündüğünü görmekteyiz. Bunun yanında öğretmenlerin sahip oldukları haklar arasında en yüksek düzeyde $(\bar{x}=4.74)$ mesleki gelecekleri ile ilgili istediği konularda araştırmalar yapabilmenin geldiği görülmüsstür. Öğretmenlerin hak sahibi olmaları gerektiğini düşündüğü konular arasında en yüksek puan ortalaması, meslektaşlarıyla bağlılık geliştirme $\quad(\bar{x}=4.34)$ gelmektedir. Bunun yanında öğretmenlerin hak sahibi olmaları gerektiğini düşündüğü konular arasında en düşük puan ortalaması ise eğitim programlarının geliştirilmesine $(\overline{\mathrm{x}}=3.80)$ aittir. Öğretmenler mesleklerinde sorumlulukları oranında $(\overline{\mathrm{x}}=3.96)$, öğrencilerinin üzerinde sahip oldukları önem oranında $(\overline{\mathrm{x}}=3.95)$ ve toplum üzerinde sorumlulukları oranında $(\overline{\mathrm{x}}=$ 
3.96) yetkiye sahip olmadıklarını yüksek düzeyde ifade etmişlerdir. Öğretmen özerkliğinin sınırlanmasına ilişkin puanlar incelendiğinde, öğretmen görüşlerine göre öğretmenlerin özerklik alanları öğretmenlerin mesleki deneyimine göre belirlenmesi gerektiğine ilişkin ifadenin en yüksek değere sahip olduğunu görmekteyiz ( $\bar{x}=4.07$ ). Buna karşın öğretmen özerkliğinin sınırlarının belirlenmesine ilişkin en düşük değer, öğretmen özerkliğinin toplum tarafindan belirlenmesine ilişkin ifadeye aittir $(\overline{\mathrm{x}}=2.99)$. Ayrıca öğretmenler, katı merkezi yönetimin öğretmen özerkliğine engel olduğuna ilişkin yüksek düzeyde $(\overline{\mathrm{x}}=4.09)$ görüş bildirmişlerdir.

\section{Algılanan Yönetim Tarzlarının ve Öğretmen Özerkliğinin Değişkenlere Göre İncelenmesi}

Bu bölümde okul yöneticilerinin algılanan yönetim tarzlarının cinsiyet, eğitim durumu, yaş, kıdem ve yöneticilik deneyimi değişkenlerine göre incelenmiştir.

\section{Cinsiyete Göre Algılanan Yönetim Tarzı ve Öğretmen Özerkliğine Illişkin Bulgular}

Okul yöneticilerinin algılanan yönetim tarzlarının ve öğretmen özerklik düzeylerinin öğretmenlerin cinsiyetine göre farklılaşıp farklılaşmadığını incelemek için, veriler normal dağıldığı ve bağımsız değişken iki düzeyi olduğu için bağımsız gruplar için t testi kullanılmıştır. Tablo 3'te cinsiyet değişkenine göre okul yöneticilerinin algılanan yönetim tarzları ve öğretmen özerkliğine ilişkin t-testi sonuçları verilmiştir.

Tablo 3. Cinsiyete Göre Yönetim Tarzı ve Öğretmen Özerkliğine İlişkin t-Testi Sonuçları

\begin{tabular}{lcccccc}
\hline Ölçek ve Boyut & Cinsiyet & $\mathrm{n}$ & $\overline{\mathrm{x}}$ & $\mathrm{t}$ & $\mathrm{df}$ & $\mathrm{p}$ \\
\hline Yönetim Tarzı & Kadın & 146 & 2.77 & .58 & 365 & .56 \\
& Erkek & 221 & 2.73 & & & \\
\hline Öğretim sürecinde & Kadın & 146 & 4.71 & 4.54 & 344.20 & $.00^{*}$ \\
Özerklik & Erkek & 221 & 4.50 & & & \\
\hline Hak sahibi olmalıdır & Kadın & 146 & 4.66 & 2.48 & 357.89 & $.01^{*}$ \\
& Erkek & 221 & 4.55 & & & \\
\hline Hak sahibidir & Kadın & 146 & 4.15 & 1.68 & 365 & .09 \\
& Erkek & 221 & 3.98 & & & \\
\hline Öğretmen Özerkliği & Kadın & 146 & 3.85 & 2.80 & 287.13 & $.00^{*}$ \\
Kriterleri & Erkek & 221 & 3.59 & & & \\
\hline
\end{tabular}


Tablo 3'e göre okul yöneticilerinin algılanan yönetim tarzları öğretmenlerin cinsiyetine göre anlamlı düzeyde farklılaşmamaktadır $(\mathrm{p}<0.05)$. Tablo 3 'teki öğretmenlerin özerklik düzeyleri incelendiğinde, öğretim sürecinde sınıf içinde, sahip olduğu haklarla ilgili görüşlerinde ve özerkliğin uygulama kriterlerinde cinsiyete göre anlamlı düzeyde farklılaşma görülmektedir $(\mathrm{p}<0.05)$. Öğretmenlerin sahip oldukları haklar ve sorumluluk düzeyleri alt boyutunda ise cinsiyet değişkeni anlamlı bir farklılık yaratmamaktadır $(\mathrm{p}>0.05)$.

Ĕ̆itim Durumuna Göre Algllanan Yönetim Tarzı ve Öğretmen Özerkliğine İlişkin Bulgular

Tablo 4'te eğitim durumu değişkenine göre okul yöneticilerinin algılanan yönetim tarzları ve öğretmen özerkliğine ilişkin t-testi sonuçları verilmiştir.

Tablo 4. Eğitim Durumuna Göre Yönetim Tarzı ve Öğretmen Özerkliğine İlişkin t-Testi Sonuçları

\begin{tabular}{lcccccc}
\hline Ölçek ve Boyut & Eğitim Durumu & $\mathrm{n}$ & $\overline{\mathrm{x}}$ & $\mathrm{t}$ & $\mathrm{df}$ & $\mathrm{p}$ \\
\hline Yönetim Tarzı & Lisan & 356 & 2.74 & .11 & 365 & .91 \\
& Yüksek Lisans & 11 & 2.72 & & & \\
\hline Öğretim sürecinde & Lisans & 356 & 4.58 & -.76 & 365 & .44 \\
Özerklik & Yüksek Lisans & 11 & 4.69 & & & \\
\hline Hak sahibi olmalıdır & Lisans & 356 & 4.59 & -.47 & 365 & .63 \\
& Yüksek Lisans & 11 & 4.66 & & & \\
\hline Hak sahibidir & Lisans & 356 & 4.04 & -1.56 & 365 & .11 \\
& Yüksek Lisans & 11 & 4.49 & & & \\
\hline Öğretmen Özerkliği & Lisans & 356 & 3.69 & -.29 & 365 & .76 \\
Kriterleri & Yüksek Lisans & 11 & 3.77 & -.76 & & \\
\hline
\end{tabular}

Tablo 4'teki bulgulara göre; öğretmenlerin eğitim durumuna göre okul yöneticilerinin algılanan yönetim tarzlarında ve öğretmen özerklik düzeylerinde anlamlı farklılık bulunmamıştır $(\mathrm{p}>0.05)$.

\section{Yaşa Göre Algılanan Yönetim Tarzı ve Öğretmen Özerkliğine İlişkin Bulgular}

Okul yöneticilerinin algılanan yönetim tarzlarının ve öğretmen özerklik düzeylerinin öğretmenlerin yaşına göre farklılaşıp farklılaşmadığını incelemek için, veriler normal dağıldığı ve bağımsız değişkenin grup sayısı ikiden fazla olduğu için ANOVA testi 
kullanılmıştır. Tablo 5'te yaş değişkenine göre okul yöneticilerinin algılanan yönetim tarzları ve öğretmen özerkliğine ilişkin ANOVA testi sonuçları verilmiştir.

Tablo 5. Yaşa Göre Algllanan Yönetim Tarzı ve Öğretmen Özerkliğine İlişkin ANOVA Testi Sonuçları

\begin{tabular}{|c|c|c|c|c|c|c|c|c|}
\hline $\begin{array}{l}\text { Ölçek ve } \\
\text { Boyut }\end{array}$ & Yaş & $\mathrm{n}$ & $\begin{array}{l}\text { Varyans } \\
\text { Kaynağ1 }\end{array}$ & $\begin{array}{l}\text { Kareler } \\
\text { Toplamı }\end{array}$ & df & $\begin{array}{c}\text { Kareler } \\
\text { Ortalamas1 }\end{array}$ & $\mathrm{F}$ & $\begin{array}{c}\text { p/Anlamlı } \\
\text { Farklılık }\end{array}$ \\
\hline Yönetim & $20-29$ & 80 & G. Aras1 & .24 & 2 & .12 & .27 & .75 \\
\hline \multirow[t]{2}{*}{ Tarzı } & $30-39$ & 158 & G. İçi & 162.23 & 364 & .44 & & \\
\hline & 40veüst & 129 & Toplam & 162.47 & 366 & & & \\
\hline \multirow{3}{*}{$\begin{array}{l}\text { Öğretim } \\
\text { sürecinde } \\
\text { özerklik }\end{array}$} & $20-29$ & 80 & G. Aras1 & 1.88 & 2 & .94 & 4.34 & $.01 *$ \\
\hline & $30-39$ & 158 & G. İçi & 78.80 & 364 & .21 & & (20-29 ile \\
\hline & 40-üstü & 129 & Toplam & 80.68 & 366 & & & $\begin{array}{c}40 \text { ve üstü) } \\
.00^{*}\end{array}$ \\
\hline \multirow{3}{*}{$\begin{array}{l}\text { Hak sahibi } \\
\text { olmalıdır }\end{array}$} & $20-29$ & 80 & G. Aras1 & .40 & 2 & .20 & .96 & .38 \\
\hline & $30-39$ & 158 & G. İçi & 75.47 & 364 & .20 & & \\
\hline & 40-üstü & 129 & Toplam & 75.87 & 366 & & & \\
\hline \multirow{3}{*}{$\begin{array}{l}\text { Hak } \\
\text { sahibidir }\end{array}$} & $20-29$ & 80 & G. Aras1 & .15 & 2 & .07 & .08 & .91 \\
\hline & $30-39$ & 158 & G. İçi & 329.27 & 364 & .90 & & \\
\hline & 40-üstü & 129 & Toplam & 329.43 & 366 & & & \\
\hline Öğretmen & $20-29$ & 80 & G. Aras1 & .04 & 2 & .02 & .02 & .97 \\
\hline Özerkliği & $30-39$ & 158 & G. İçi & 290.12 & 364 & .79 & & \\
\hline Kriterleri & 40-üstü & 129 & Toplam & 290.17 & 366 & & & \\
\hline
\end{tabular}

Tablo 5.'teki bulgulara göre; öğretmenlerin yaşlarına göre okul yöneticilerinin algılanan yönetim tarzlarında anlamlı farklılık bulunmamıştır ( $p>0.05)$. Bunun yanında yaşa göre öğretmenlerin sınıf içi öğretim süreçlerindeki özerklik düzeylerinde anlamlı farklılık görülmüştür $(\mathrm{p}<0.05)$. Diğer boyutlarda yaş değişkenine göre anlamlı bir farklılık tespit edilmemiştir ( $>00.05)$. Hangi grupların arasında anlamlı farklılık olduğuna ilişkin yapılan Post Hoc testler sonucunda 20-29 yaş grubu öğretmenlerin sınıf içi öğretim süreçlerinde, 40 yaş ve üstü öğretmenlere oranla daha yüksek düzeyde özerk olmak istedikleri görülmüştür $(\mathrm{p}<0.05)$. Genç öğretmenler, yenilik ve değişime daha açık ve isteklidirler.

Kıdeme Göre Okul Yöneticilerinin Algılanan Yönetim Tarzı ve Öğretmen Özerkliğine İlişkin Bulgular

Tablo 6'da kıdem değişkenine göre okul yöneticilerinin algılanan yönetim tarzları ve öğretmen özerkliğine ilişkin ANOVA testi sonuçları verilmiştir. 
Tablo 6. Kıdeme Göre Algılanan Yönetim Tarzı ve Öğretmen Özerkliği Düzeyine İlişkin ANOVA Testi Sonuçları

\begin{tabular}{|c|c|c|c|c|c|c|c|c|}
\hline $\begin{array}{l}\text { Ölçek } \\
\text { Boyutları }\end{array}$ & Kıdem & $\mathrm{n}$ & $\begin{array}{l}\text { Varyans } \\
\text { Kaynağ1 }\end{array}$ & $\begin{array}{l}\text { Kareler } \\
\text { Toplam }\end{array}$ & $\mathrm{df}$ & $\begin{array}{c}\text { Kareler } \\
\text { Ortalma }\end{array}$ & $\mathrm{F}$ & $\begin{array}{c}\text { p/Anlamlı } \\
\text { Farklılik }\end{array}$ \\
\hline \multirow{3}{*}{$\begin{array}{l}\text { Yönetim } \\
\text { Tarzı }\end{array}$} & 10 ve az & 160 & G. Aras1 & 2,27 & 2 & 1,13 & 2,58 &, 07 \\
\hline & $11-20 y_{1} 1$ & 149 & G. İçi & 160,20 & 364 &, 44 & & \\
\hline & 21 üstü & 58 & Toplam & 162,47 & 366 & & & \\
\hline \multirow{3}{*}{$\begin{array}{l}\text { Öğretim } \\
\text { sürecinde } \\
\text { özerklik }\end{array}$} & $10 \mathrm{ve} a z$ & 160 & G. Arası & 1,32 & 2 & ,66 & 3,04 & \multirow{3}{*}{$\begin{array}{c}, 04^{*} \\
(10 \text { ve alt/ } \\
11-20), 03^{*}\end{array}$} \\
\hline & 11-20y1l & 149 & G. İçi & 79,35 & 364 &, 21 & & \\
\hline & 21 üstü & 58 & Toplam & 80,68 & 366 & & & \\
\hline \multirow{3}{*}{$\begin{array}{l}\text { Hak } \\
\text { sahibi } \\
\text { olmalıdır }\end{array}$} & 10 ve az & 160 & G. Arası &, 41 & 2 & ,20 & 1,00 &, 36 \\
\hline & 11-20y1l & 149 & G. İçi & 75,46 & 364 &, 20 & & \\
\hline & 21 üstü & 58 & Toplam & 75,87 & 366 & & & \\
\hline \multirow{3}{*}{$\begin{array}{l}\text { Hak } \\
\text { sahibidir }\end{array}$} & 10 ve az & 160 & G. Arası & 1,13 & 2 & ,57 & ,63 & ,53 \\
\hline & $11-20 y 11$ & 149 & G. İçi & 328,29 & 364 & ,90 & & \\
\hline & 21 üstü & 58 & Toplam & 329,43 & 366 & & & \\
\hline \multirow{3}{*}{$\begin{array}{l}\text { Öğretme } \\
\mathrm{n} \\
\text { Özerkliği } \\
\text { Kriterleri }\end{array}$} & 10 ve az & 160 & G. Arası &, 85 & 2 &, 42 &, 53 & ,58 \\
\hline & 11-20yıl & 149 & G. İçi & 289,32 & 364 & ,79 & & \\
\hline & 21 üstü & 58 & Toplam & 290,17 & 366 & & & \\
\hline
\end{tabular}

Tablo 6'daki bulgulara göre, öğretmenlerin kıdemine göre okul yöneticilerinin algılanan yönetim tarzlarında anlamlı farklılık bulunmamıştır $(\mathrm{p}>0.05)$. Kıdeme göre öğretmenlerin sınıf içi öğretim süreçlerinde özerklik düzeylerinde anlamlı farklılık görülmektedir $(\mathrm{p}<0.05)$. Diğer boyutlarda kıdem değişkenine göre anlamlı bir farklılık tespit edilmemiştir ( $>00.05$ ). Hangi grupların arasında anlamlı farklılık olduğuna ilişkin yapılan Post Hoc testler sonucunda 10 yıl ve daha az süreli kıdeme sahip öğretmenler, 11 ve 20 yıl arası kıdeme sahip öğretmenlere oranla sınıfiçinde daha fazla özerkliğe sahip olmak istemektedirler. Yaş değişkeninde olduğu gibi mesleki deneyim değişkeninde de 10 yıl ve daha az kıdeme sahip öğretmenler daha çok özerk olmak istedikleri sonucu ortaya çıkmaktadır.

Yöneticilik Deneyimine Göre Okul Yöneticilerinin Algllanan Yönetim Tarzl ve Öğretmen Özerkliğine İlişkin Bulgular

Tablo 7'de yöneticilik değişkenine göre okul yöneticilerinin algılanan yönetim tarzları ve öğretmen özerkliğine ilişkin ANOVA testi sonuçları verilmiştir. 
Tablo 7. Yöneticilik Deneyimine Göre Algllanan Yönetim Tarzı ve Öğretmen Özerkliğ $i$ Düzeyine İlişkin ANOVA Testi Sonuçları

\begin{tabular}{|c|c|c|c|c|c|c|c|c|}
\hline Ölçek & Kıdem & $\mathrm{n}$ & $\begin{array}{l}\text { Varyans } \\
\text { Kaynağ } 1\end{array}$ & $\begin{array}{c}\text { Kareler } \\
\text { Toplamı }\end{array}$ & df & $\begin{array}{c}\text { Kareler } \\
\text { Ortalaması }\end{array}$ & F & $\begin{array}{c}\text { p/Anlamlı } \\
\text { Farklılık }\end{array}$ \\
\hline \multirow{4}{*}{ 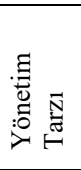 } & Yok & 186 & G. Aras1 & 3,25 & 2 & 1,62 & 3,72 &, $02 *$ (Yok- \\
\hline & 10 ve & 108 & G. İçi & 159,21 & 364 &, 43 & & 10 ve alt) \\
\hline & $\mathrm{az}$ & & & & & & &, $040^{*}$ \\
\hline & $\begin{array}{l}11 \mathrm{ve} \\
\text { üst }\end{array}$ & 47 & Toplam & 162,47 & 366 & & & \\
\hline \multirow{3}{*}{ 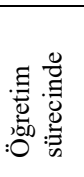 } & Yok & 186 & G. Aras1 & ,21 & 2 &, 10 & ,47 & ,62 \\
\hline & $\begin{array}{c}10 \mathrm{ve} \\
\mathrm{az}\end{array}$ & 108 & G. İçi & 80,47 & 364 & ,22 & & \\
\hline & $\begin{array}{l}11 \mathrm{ve} \\
\text { üst }\end{array}$ & 47 & Toplam & 80,68 & 366 & & & \\
\hline \multirow{3}{*}{ 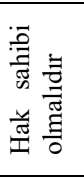 } & Yok & 186 & G. Aras1 & ,55 & 2 & ,27 & 1,33 & ,26 \\
\hline & $\begin{array}{c}10 \text { ve } \\
\text { az }\end{array}$ & 108 & G. İçi & 75,32 & 364 &, 20 & & \\
\hline & $\begin{array}{c}11 \text { ve } \\
\text { üst }\end{array}$ & 47 & Toplam & 75,87 & 366 & & & \\
\hline \multirow{3}{*}{ 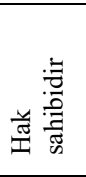 } & Yok & 186 & G. Aras1 & ,90 & 2 & ,45 &, 50 & ,60 \\
\hline & $\begin{array}{c}10 \mathrm{ve} \\
\mathrm{az}\end{array}$ & 108 & G. İçi & 328,52 & 364 &, 90 & & \\
\hline & $\begin{array}{c}11 \mathrm{ve} \\
\text { üst }\end{array}$ & 47 & Toplam & 329,43 & 366 & & & \\
\hline \multirow{3}{*}{ 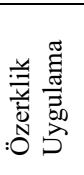 } & Yok & 186 & G. Aras1 & 6,92 & 2 & 3,46 & 4,44 &, $01 *$ (Yok- \\
\hline & $\begin{array}{c}10 \mathrm{ve} \\
\mathrm{az}\end{array}$ & 108 & G. İçi & 283,25 & 364 &, 77 & & $\begin{array}{c}11 \text { ve üst) } \\
, 01 *\end{array}$ \\
\hline & $\begin{array}{c}11 \mathrm{ve} \\
\text { üst }\end{array}$ & 47 & Toplam & 290,17 & 366 & & & \\
\hline
\end{tabular}

Tablo 7'deki bulgulara göre, öğretmenlerin yöneticilik deneyimi okul yöneticilerinin algılanan yönetim tarzlarında anlamlı farklılık meydana getirmektedir $(p<0.05)$. Hangi grupların arasında anlamlı farklılık olduğuna ilişkin yapılan Post Hoc testler sonucunda yöneticilik deneyimi olmayanlar ile 10 yıl ve daha kısa süreli yöneticilik deneyimine sahip olan öğretmenler arasında algılanan yönetim tarzında anlamlı farklılık oluşturduğu görülmektedir $(\mathrm{p}<0.05)$. Yine Tablo 7'ye göre yöneticilik deneyimine göre öğretmenlerin, öğretmen özerkliğinin kriterlerine ilişkin görüşlerinde anlamlı farklılık olduğu görülmektedir $(\mathrm{p}<0.05)$. Hangi grupların arasında anlamlı farklılık olduğuna ilişkin yapılan Post Hoc testler sonucunda yöneticilik deneyimine sahip olmayan öğretmenler ile 11 yıl ve daha fazla yöneticilik deneyimine sahip öğretmenlerin, öğretmen özerkliğinin kriterlerine ilişkin görüşleri arasında anlamlı farklılık oluşmaktadır $(\mathrm{p}<0.05)$. 


\section{Yönetim Tarzları ve Öğretmen Özerkliği Arasındaki İlişkiye İlişkin Bulgular}

Okul yöneticilerinin algılanan yönetim tarzları ile öğretmen özerklik düzeyleri arasındaki ilişkiyi belirlemek amacıyla korelasyon analizi yapılmıştır. Tablo 8'de okul yöneticilerinin algılanan yönetim tarzları ile öğretmen özerklik düzeyleri arasındaki ilişkinin pearson analizi sonuçları verilmiştir.

Tablo 8. Okul Yöneticilerinin Algllanan Yönetim Tarzları ve Öğretmenlerin Ö̈erklik Düzeyleri Arasındaki İlişkinin Korelasyon Değerleri

\begin{tabular}{|c|c|c|c|c|c|}
\hline Boyutlar & & irlikli & $\begin{array}{l}\text { Otoriter } \\
\text { Yönetim }\end{array}$ & $\begin{array}{c}\text { İlgisiz } \\
\text { Yönetim }\end{array}$ & $\begin{array}{c}\text { Karş1 Koyucu } \\
\text { Yönetim }\end{array}$ \\
\hline \multirow{3}{*}{$\begin{array}{l}\text { Öğretim sürecinde } \\
\text { özerklik }\end{array}$} & $\mathrm{r}$ & $.205 * *$ & -.007 & .060 & -.011 \\
\hline & $\mathrm{p}$ & .000 & .899 & .255 & .838 \\
\hline & $\mathrm{n}$ & 367 & 367 & 367 & 367 \\
\hline \multirow{3}{*}{ Hak sahibi olmalıdır } & $\mathrm{r}$ & .096 & -.001 & .006 & .005 \\
\hline & $\mathrm{p}$ & .066 & .990 & .916 & .921 \\
\hline & $\mathrm{n}$ & 367 & 367 & 367 & 367 \\
\hline \multirow{3}{*}{ Hak sahibidir } & $\mathrm{r}$ & $.274 * *$ & .046 & $.128 *$ & .003 \\
\hline & $\mathrm{p}$ & .00 & .38 & .01 & .947 \\
\hline & $\mathrm{n}$ & 367 & 367 & 367 & 367 \\
\hline \multirow{3}{*}{$\begin{array}{c}\text { Öğretmen Özerkliği } \\
\text { Kriterleri }\end{array}$} & $r$ & $.120 *$ & $.273 * *$ & $.231 * *$ & $.139 * *$ \\
\hline & $\mathrm{p}$ & .021 & .000 & .000 & .008 \\
\hline & $\mathrm{n}$ & 367 & 367 & 367 & 367 \\
\hline
\end{tabular}

** $\mathrm{p}<0.01$ düzeyinde çift yönlü ilişki

$* p<0.05$ düzeyinde çift yönlü ilişki

Tablo 8'de görüldüğü üzere, öğretim sürecinde sınıf içinde öğretmenin özerkliği ile işbirlikli yönetim tarzı arasında pozitif yönlü düşük düzeyde (r=.205) çift yönlü ve anlamlı bir ilişki $(\mathrm{p} \leq 0.01)$ bulunmuştur. Öğretmenlerin hak sahibi olduğu hususlar ile yönetim tarzları arasındaki en yüksek ilişkisi olan yönetim tarzı, işbirlikli yönetim tarzı arasında pozitif yönlü düşük düzeyde $(\mathrm{r}=.274)$ çift yönlü ve anlamlı bir ilişki $(\mathrm{p} \leq 0.01)$ bulunmuştur. Öğretmen özerkliğinin kriterlerine ilişkin öğretmen görüşleri ile yönetim tarzları arasındaki en yüksek ilişkisi olan yönetim tarzı, otoriter yönetim tarzı arasında pozitif yönlü düşük düzeyde $(r=.273)$ çift yönlü ve anlamlı bir ilişki $(p \leq 0.01)$ bulunmuştur.

Korelasyon analizi sonucuna göre değişkenler arasında anlamlı ilişkiler bulunduğundan değişkenler regresyon analizine tabi tutulmuştur. Öğretim sürecinde öğretmen özerkliği, eğitim sisteminde öğretmen özerkliği, öğretmenlerin hak ve sorumluluk düzeyleri ve 
öğretmen özerkliği uygulamaları değişkenlerine göre algılanan yönetim tarzının yordanmasına ilişkin regresyon analizi sonuçları Tablo 9'da verilmiştir.

Tablo 9. Yönetim Tarzları ve Öğretmen Özerkliğine İlişkin Regresyon Model Özeti

\begin{tabular}{lccccccc}
\hline Değişken & $\mathrm{B}$ & $\begin{array}{c}\text { Standart } \\
\text { Hata B }\end{array}$ & $\beta$ & $\mathrm{T}$ & $\mathrm{p}$ & İkili r & Kısmi R \\
\hline Sabit & 2.106 & .370 & & 5.694 & .000 & - & - \\
\hline $\begin{array}{l}\text { Öğretim } \\
\text { Sürecinde Ö.Ö. }\end{array}$ & .037 & .094 & .026 & .397 & .691 & .087 & .021 \\
$\begin{array}{l}\text { Hak sahibi } \\
\text { olmalıdır }\end{array}$ & -.109 & .094 & -.075 & -1.161 & .246 & .038 & -.061 \\
$\begin{array}{l}\text { Hak sahibidir } \\
\text { Öğretmen }\end{array}$ & .045 & .040 & .064 & 1.119 & .264 & .165 & .059 \\
özerkliği kriterleri & .215 & .042 & .287 & 5.157 & .000 & .300 & .262 \\
$\mathrm{R}=0.310, \mathrm{R}^{2}=0.096, \mathrm{~F}=9.603, \mathrm{p}=.001$ & & & & &
\end{tabular}

Tablo 9'da, öğretim sürecinde (sınıf içinde) öğretmen özerkliği, öğretmenlerin hak sahibi olması gerektiğini düşündüğü hususlar, öğretmenlerin hak sahibi olduğu hususlar ve öğretmen özerkliği kriterleri değişkenleri birlikte, okul yöneticilerinin algılanan yönetim tarzlarını orta düzeyde ve anlamlı bir ilişki görülmektedir $\left(\mathrm{R}=0.310, \mathrm{R}^{2}=0.96\right.$, $\mathrm{p}<.01$ ). Adı geçen dört değişkenle birlikte, algılanan yönetim tarzlarındaki toplam varyansın yaklaşık \%9'unu açıklamaktadır. Bu bulgulardan, öğretmenlerin çeşitli boyutlarda özerklik düzeylerini etkileyen değişkenlerden biri de yöneticilerin yönetim tarzı olduğu sonucuna varılmıştır. Regresyon katsayılarının anlamlılı̆ı̆ına ilişkin t-testi sonuçları incelendiğinde, sadece öğretmen özerkliği kriterleri değişkeninin, algılanan yönetim tarzı üzerinde anlamlı bir yordayıcı olduğu görülmektedir.

\section{TARTIŞMA ve SONUÇ}

Öğretmenlerin okul yöneticilerinin yönetim tarzlarını yüksek düzeyde işbirlikli olarak algılanması okul iklimini ve dolayısıyla okul etkililiğini olumlu yönde etkileyen bir durumdur (Çelik, 2012). Günümüz okulları, işgörenler arasında işbirlikçi ve demokratik ilişkilerin kurulduğu yapılardır (Kürkçü, 2019). Okul yöneticilerinin işbirliğine açık olması, öğretmenlerin yönetim süreçlerine katılması anlamına gelmektedir. İşbirlikli yönetim tarzında öğretmenlerin sahip oldukları hak ve sorumluluklarının oranı da 
artmaktadır. Destekleyici liderlik kapsamında okul müdürlerinin işbirlikçi öğrenme ortamlarını sağlaması ve mesleki gelişimi destekleyici uygulamalar yapması öğretmenlerin özerklik düzeyini arttırmaktadır (Garvin, 2007).

Öğretmenlerin sınıf içindeki özerklik düzeylerinde en yüksek özerklik düzeyini, öğretim sürecinde farklı yöntemler kullanma konusunda talep ettikleri görülmektedir. (Friedman, 1999). Karasu ve Avcı (2019) araştırmasında, farklı öğretim yöntem ve teknikleri kullanma konusunda öğretmenlerin çoğunluğu kendisini yeterli gördüğünü tespit etmiştir. Yöntem ve teknikleri kullanma konusunda kendilerini yetersiz bulan öğretmenler, yetersiz bulma nedenlerini materyal yetersizliği, sınıf mevcudu, öğrenci seviyesi, mesleki deneyimsizlik ve ders sürelerinin yetersizliği ile bu durumu açıklamışlardır. Benzer şekilde Doğru ve Aydoğdu (2003) sınıf mevcudunun; Çelikkaya ve Kuş (2009) sınıf ortamının, ders sürelerinin, öğretmenlerin bilgi eksikliğinin; Demir ve Özden (2013), materyal yetersizliğinin farklı öğretim yöntem ve teknikleri kullanma konusunda engel olduğu sonucuna ulaşmışlardır. Yapılan araştırmalar da dikkate alındığında öğretmenlerin sınıf içinde farklı öğretim yöntem ve tekniklerinin kullanabilmesi yönünde özerklik alanlarının genişletilebilmesi aynı zamanda okulun fiziksel gereksinimlerinin giderilmesinin yanında eğitim sisteminde özellikle ders sürelerinin esnekliğine ilişkin düzenlemelerin yapılmasını da gerekmektedir. Yine araştırmalarda tespit edilen öğretmenlerin bu konudaki bilgi eksikliklerinin giderilmesi için de Bakanlık bünyesinde hizmetiçi eğitimler ve projeler geliştirilmesi gerekmektedir.

Bunun yanında öğretmenlerin hak sahibi olması gerektiğini en yüksek düzeyde düşündüğü hususun, mesleki gelecekleri ile ilgili istediği konularda araştırmalar yapabilmek olduğu görülmektedir. Elde edilen bulgulara göre, öğretmenlerin kendilerini mesleki anlamda geliştirebilmeleri için gerekli hizmet içi eğitimlerin Bakanlık tarafından düzenlenmesinin yanında kendi tercihleri doğrultusunda akademik kariyerlerini geliştirecek lisansüstü programlara katılmalarının da desteklenmesi gerektiği sonucuna ulaşılmaktadır. Öğretmenlerin profesyonel gelişimi, hizmet içi 
eğitimler, seminerler, kurslar, çalıştaylar gibi uygulamalarla sürekli olarak desteklenmelidir (Gül, 2016).

Öğretmen görüşlerine göre, öğretmenler en yüksek düzeyde meslektaşlarıyla bağl1lık geliştirme hakkına sahiptirler. Okul yöneticilerinin öğretmenler arasında sosyal ilişkileri geliştirecek bir yönetim tarzı sergilemeleri önemlidir. Bu sayede uygulamış oldukları yönetim teknikleri ile eğitimin ana paydaşlarından olan öğretmenlerin daha nitelikli eğitim öğretim süreci yürütmesi, pozitif ilişkiler etrafinda okul kültürüne katkı sağlaması ve daha iyi bir okul iklimine sahip olunması mümkün olacaktır (TEDMEM, 2015). Bunun yanında öğretmenlerin, ise eğitim programlarının şekillendirilmesinde en düşük düzeyde hak sahibi oldukları görüşünde oldukları görülmektedir. Bu bulgu ise eğitim sisteminin katı merkezi yapısının bir yansıması olarak değerlendirilebilir.

Öğretmenler mesleklerinde sorumlulukları oranında, öğrencilerinin üzerinde sahip oldukları önem oranında ve toplum üzerinde sorumlulukları oranında yetkiye sahip olmadıklarını ifade etmişlerdir. Öğretmenlerin kendilerinden beklenen rolleri yerine getirebilmesi için mesleki sorumlulukları ve öğrenci ve toplum için önemleri oranında yetkilendirilmesi ve hak ettikleri itibara kavuşmaları gerekmektedir (Yıldırım, Ünal ve Çelik, 2011).

Öğretmen görüşlerine göre özerklik düzeyi öğretmenlerin mesleki deneyimine göre belirlenmesi gerekmekte olduğu tespit edilmiştir. Öğretmenlik mesleğinde deneyimin getirdiği kişisel ve mesleki birikimin, öğretmenin kendine mesleki anlamda daha fazla güvenmesinin yanında özerk davranma eğilimini de artıracağı düşünülmektedir. Koşar (2019), öğretmenlerin deneyimlerinden hareketle öğretmenliğin hayata dokunma, çok yönlü olma, kendini yenileme, yol gösterme, ufuk açma, zorluklarla mücadele edebilme olmak üzere altı temel bileşenden oluştuğu sonucuna ulaşmıştır. Bu bileşenlerin hayata geçebilmesi için hem sınıf içinde hem de eğitim sisteminin bütününde öğretmenlere daha fazla özerklik sağlanması gerekmektedir. Bununla birlikte öğretmenlerin, katı merkezi yönetimin öğretmen özerkliğine engel olduğuna ilişkin görüşleri de bu sonucu destekler niteliktedir. Öğretmen özerklik düzeyinin belirlenmesi toplumsal bask1 gruplarına bırakılmamalı, yasalarla güvence altına alınmalıdır. Bu açıdan yasalarda 
yapılacak düzenlemeler yoluyla öğretmenlere geniş hareket alanları oluşturulmalı, kendi alanlarında yetki ve sorumluluk sahibi olmaları sağlanmalıdır.

Araştırmadan elde dilen bulgular incelendiğinde okul yöneticilerinin algılanan yönetim tarzları öğretmenlerin cinsiyetine, eğitim durumuna, yaşlarına ve kıdemlerine göre anlamlı düzeyde farklılaşmadığı sonucuna ulaşılmıştır. Araştırmalarında cinsiyetin algılanan yönetim tarzında anlamlı farklılık yarattığı sonucuna ulaşan Sarı, Yıldız ve Canoğulları (2018), erkek öğretmenlerin okul yöneticilerinin yönetim tarzlarını işbirlikli, kadın öğretmenlerin ise karşı koyucu algıladıklarını belirtmişlerdir. Bunun yanında, öğretmenlerin yöneticilik deneyimi okul yöneticilerinin algılanan yönetim tarzlarında anlamlı farklılık meydana getirdiği sonucuna da ulaşılmıştır. Yöneticilik deneyimi olmayan öğretmenler ile 10 yıl ve daha kısa süreli yöneticilik deneyimine sahip olan öğretmenler arasında algılanan yönetim tarzında anlamlı farklılık oluşturduğu görülmektedir. Yöneticilik deneyimine sahip olmanın öğretmenin yöneticisinin yönetim tarzına ilişkinin algısını değiştirmesi beklenen bir durumdur. Yönetim eylemleri hakkında bilgi sahibi olan, yönetim ile ilgili oluşabilecek beklenmedik durumlar karşısında deneyimli olan öğretmenlerin algılanan yönetim tazrlarının yöneticilik deneyimi olmayan öğretmenlerden farklı olması, yöneticilik deneyiminin okul yönetimi ile ilgili öğretmene sağladığı özelliklerdendir.

Öğretmenlerin özerklik düzeyinin değişkenlere göre incelenmesine ilişkin araştırma bulgularına göre, öğretim sürecinde sınıf içinde, öğretmenlerin hak sahibi olması gerektiğini düşündüğü konularda ve öğretmen özerkliği kriteleri boyutlarında özerklik düzeyinin cinsiyete göre anlamlı düzeyde farklılaşmakta olduğu görülmüştür. Kadın öğretmenlerin üç alt boyutta da özerklik düzeylerinin yüksek olması kadın öğretmenlerin daha fazla özerkliğe sahip olmak isteklerini ortaya koymaktadır. Öğretmenlerin sahip oldukları haklara ilişkin görüşlerinde ise cinsiyet değişkeni anlamlı bir farklılık yaratmamaktadır .

Öğretmenlerin yaşına göre sadece sınıf içi öğretim süreçlerindeki özerklik düzeylerinde anlamlı farklılık görülmüştür. 20-29 yaş grubu öğretmenlerin sınıf içi öğretim süreçlerinde, 40 yaş ve üstü öğretmenlere oranla daha yüksek düzeyde özerk olmak 
istedikleri görülmüştür. Genç öğretmenler, yenilik ve değişime daha açık ve isteklidirler. Benzer şekilde Şakar (2013) ve Üzüm (2014) araştırmalarında genç öğretmenlerin ileri yaş grubundaki öğretmenlere göre özerklik düzeylerinin daha yüksek olduğu sonucuna ulaşmıştır.

Araştırmada incelenen bir diğer değişken olan kıdem değişkenine göre öğretmenlerin sınıf içi öğretim süreçlerinde özerklik düzeylerinde anlamlı farklılık görülmüştür. Buna göre, 10 yıl ve daha az süreli kıdeme sahip öğretmenler, 11 ve 20 yıl arası kıdeme sahip öğretmenlere oranla sınıf içinde daha fazla özerkliğe sahip olmak istemektedirler. Yaş değişkeninde olduğu gibi mesleki deneyim değişkeninde de 10 yıl ve daha az kıdeme sahip öğretmenler daha çok özerk olmak istedikleri sonucu ortaya çıkmaktadır. $\mathrm{Bu}$ araştırma sonuçlarını destekler şekilde Şentürken'in (2018) araştırmasında da mesleki kıdemi az olan öğretmenlerin özerklik puanlarının daha yüksek çıktığı sonucuna ulaşmıştır.

Yöneticilik deneyimi değişkenine göre ise öğretmenlerin, öğretmen özerkliğinin kriterlerine ilişkin görüşlerinde anlamlı farklılık olduğu görülmektedir. Yöneticilik deneyimine sahip olmayan öğretmenler ile 11 yıl ve daha fazla yöneticilik deneyimine sahip öğretmenlerin, öğretmen özerkliğinin kriterlerine ilişkin görüşleri arasında anlamlı farklılık oluşmaktadır. $\mathrm{Bu}$ araştırma sonuçlarını destekler nitelikte Gül (2016), yöneticilik deneyimine sahip öğretmenlerin bağımsız ve kendine özgü çalışmalar yapabildikleri sonucuna ulaşmıştır. Öğretmen Özerkliği Ölçeği’nin, öğretmen özerkliğinin nasıl belirlenmesi gerektiğini ortaya çıkarmaya yönelik görüşleri içeren boyutunda, öğretmenlerin yöneticilik deneyiminin özerklik düzeyini etkilemesi yöneticilik deneyiminin öğretmenlerin özerkliğe bakışında farklılık yarattığına işaret eder. Bu durum, yöneticilik deneyiminin öğretmenlere kazandırdığı farklı bakış açısı olarak yorumlanabilir.

Yönetim tarzları ve öğretmen özerkliği arasındaki ilişkiye ilişkin bulgular incelendiğinde öğretim sürecinde sınıf içinde öğretmenin özerkliği ile işbirlikli yönetim tarzı arasında pozitif yönlü, düşük düzeyde, çift yönlü ve anlamlı bir ilişki olduğu tespit edilmiştir. Öğretim sürecinde sınıf içinde öğretmen özerkliği, öğretmenlerin hak sahibi 
olması gerektiğini düşündüğü hususlar, öğretmenlerin hak sahibi olduğu hususlar ve öğretmen özerkliği kriterleri değişkenleri birlikte, algılanan yönetim tarzlarındaki toplam varyansın yaklaşık \%9'unu açıklamaktadır. Bu bulgulardan, öğretmenlerin çeşitli boyutlarda özerklik düzeylerini etkileyen değişkenlerden biri de yöneticilerin yönetim tarzı olduğu sonucuna varılmıştır.

Yöneticilerin çalışanları yönetime ortak ettikleri yönetim tarzına işbirlikli yönetim tarzı denilir. Demokratik bir tavır sergileyen okul yöneticileri, öğretmenlerle işbirliği yaparak okulu yönetmeleri öğretmen özerkliğinin uygulanabilirliği ve geliştirilmesine büyük katkı sunacağı anlaşılmaktadır. Bu bağlamda okul müdürü, işbirlikli yönetim tarzını sergileyerek öğretmenlerin yönetim sürecine aktif katılması firsatını verebilir, kararlarda söz sahibi olmasını sağlayabilir, böylece okula yönelik olumsuz tutumlarının da önüne geçebilir (Gedik ve Üstüner, 2019).

Sonuç olarak, okul yöneticilerinin sergilediği yönetim tarzının uygun, olumlu ve işbirliğine dayalı olması durumunda öğretmen özerkliğinin geliştirilmesi ve korunmasına katkı sağladığı, olumsuz olması durumunda ise öğretmenlerin görev ve sorumluluk alanını daralmasına neden olduğu görülmektedir. Okul yöneticileri öğretmenleri yönetim ve karar alma süreçlerine katmalı, onlarla yetki ve sorumluluklarını paylaşmalı, öğretmenlerin sınıf içerisinde istedikleri gibi bir öğretim yapmaları için gerçek anlamda özerklik sağlamalıdır. Araştırmada elde edilen bulgular doğrultusunda öğretmenlere okul yönetimine daha fazla katılma hakkı ve sorumluluğu verilmesi gerekliliği sonucuna ulaşılmaktadır. Türkiye’de Öğretmenlik Meslek Kanunu çıkarılmalı ve bu kanunla öğretmenlere istenilen düzeyde öğretmen özerkliği sağlanmalıdır. Bunun yanında ülkemizde öğretmen özerkliğinin korunması adına öğretmenlere verilen ikincil birçok görevin kaldırılması gerekmektedir. Okul yöneticiliği gibi önemli bir meslek bile yönetmeliklerde öğretmenler için ikincil bir görev olarak tanımlanmaktadır. Mevzuatta yapılacak düzenlemeler ile bu sorunların giderilmesi hem yöneticiler hem de öğretmenler için önemli oranda özerklik sağlayacaktır. Öğretmen özerkliği ile ilgili yapılacak yeni araştırmaların farklı örneklem grupları ve farklı araştırma yöntemleri kullanılarak yürütülmesi ve ayrıca öğretmen 
özerkliği kavramının alanyazındaki diğer kavramlarla ilişkisinin araştırılmasının da alanyazına faydalı olacağı düşünülmektedir.

\section{KAYNAKLAR}

Açıkalın, A. (2000). İlköğretim okulu yöneticilerinin dönüşümcü liderlik özellikleri ile empati becerileri arasındaki ilişki, (Yüksek Lisans Tezi). Gazi Üniversitesi Eğitim Bilimleri Enstitüsü, Ankara.

Akçay, P. (2020). Okul Yöneticilerinin Algılanan Yönetim Tarzlarının Değerler Çerçevesinde İncelenmesi. Akdeniz Üniversitesi Eğitim Fakültesi Dergisi,3(2), $19-32$.

Alanoğlu, M \& Demirtaş, Z. (2019). Bürokratik okul yapısı ile müdür yönetim tarzları arasındaki ilişkilerin incelenmesi. Pamukkale Üniversitesi Eğitim Fakültesi Dergisi, 48, 199-213.

Başaran, İ. E. (2000). Yönetim (3. Baskı). İstanbul: Umut Yayım Dağıtım.

Başaran, Y. K. (2017). Sosyal Bilimlerde Örnekleme Kuram1, Akademik Sosyal Araştırmalar Dergisi, (5)47, 480-495

Büyüköztürk, Ş. (2012). Bilimsel Araştırma Yöntemleri (Geliştirilmiş 13. Bask1). Ankara: Pegem Akademi.

Çelik, V. (2012). Okul Kültürü ve Yönetimi. Ankara: Pegem Yayınevi.

Çelikkaya, T. \& Kuş, Z. (2009). Sosyal Bilgiler öğretmenlerinin kullandıkları yöntem ve teknikler. Uludă̆ Üniversitesi Eğitim Fakültesi Dergisi, 22(2), 741-758

Demir, S. \& Özden, S. (2013). Sınıf öğretmenlerinin öğretimsel stratejilere yöntemlere ve tekniklere ilişkin görüşleri: Hayat Bilgisi dersine yönelik tanılayıcı bir çalışma. Pamukkale Üniversitesi Sosyal Bilimler Enstitüsü Dergisi, 14, 59-75.

Demir, E., Saatçioğlu, Ö \& İmrol, F. (2016). Uluslararası dergilerde yayımlanan eğitim araştırmalarının normallik varsayımları açısından incelenmesi, Current Research in Education, (2)3, 130-148.

Doğru, M. \& Aydoğdu, M. (2003). Fen Bilgisi öğretiminde kullanılan yöntemlerde karşılaşılan sorunlar ile ilgili öğrenci görüşleri. Pamukkale Üniversitesi Eğitim Fakültesi Dergisi, 1(13), 150-158.

Eren, E. (2011). Yönetim ve Organizasyon. İstanbul: Beta Basım Yayım.

Friedman, I. A. (1999). Teacher-perceived work autonomy: The concept and its measurement. Educational and Psychological Measurement, (59)1, 58-76.

Garvin, N. M. (2007). Teacher autonomy: Distinguishing perceptions by school cultural characteristics (Doctoral Dissertation). Universty of Pennsylvania. 
Gedik, A. \& Üstüner, M. (2019). Öğretmenlerin örgütsel sinizm düzeylerine algıladıkları müdür yönetim tarzının etkisi. Pamukkale Üniversitesi Sosyal Bilimler Enstitüsü Dergisi, 37, 53-68.

Gül, F. Ö. (2016). Eğitimsel liderlik uygulamaları bağlamında öğretmen özerkliğinin incelenmesi, (Yayınlanmamış Yüksek Lisans Tezi). Marmara Üniversitesi, Eğitim Bilimleri Enstitüsü, İstanbul.

Gürsoy, F. (2020). Ortaokullarda çalışan öğretmenlerin öğretmen özerkliğine ilişkin algı düzeyleri, (Yayınlanmamış Yüksek Lisans Tezi). Dokuz Eylül Üniversitesi Eğitim Bilimleri Enstitüsü, İzmir.

Karasu Avcı, E., \& Ketenoğlu Kayabaşı, Z. E. (2019). Sınıf öğretmenlerinin derslerinde kullandıkları yöntem ve tekniklere ilişkin görüşleri: Bir olgubilim araştırması. Hacettepe Üniversitesi Eğitim Fakültesi Dergisi, 34(4), 926-942. doi: 10.16986/HUJE.2018044069.

Koşar, D. (2019). Öğretmenlerin mesleki deneyimlerinin incelenmesi: öğretmen olmanın anlamına ilişkin fenomenolojik bir çalışma. Journal of History Culture and Art Research, 8(2), 333-346. doi:http://dx.doi.org/10.7596/taksad.v8i2.2122. 22 Mart 2021.

Kürkçü, M. (2019). Sınıf öğretmenlerinin ögretmen özerkliği davranışları akademik iyimserlik düzeyleri ve öğretmen liderliği alglları arasındaki ilişki, (Yayınlanmış Yüksek Lisans Tezi). Amasya Üniversitesi Eğitim Bilimleri Enstitüsü, Amasya.

Oğuzkan, A. F. (1993). Eğitim terimleri sözlüğü. Ankara: Emel Matbaacılık.

Pearson, L. C. ve Moomaw, W. (2005). The relationship between teacher autonomy andstress, worksatisfaction, empowerment and professionalism, Educational Research Quarterly. 29(1), 37-53.

Robbins, S. P., Decenzo, D. A. \& Coulter, M. (2013). Yönetimin esaslarl: Temel kavramlar ve uygulamalar, Çev. Ed. A. Öğüt. Ankara: Nobel.

Sarı, M., Yıldız, E. ve Canoğulları, E. (2018). Öğretmenlerin algıladıkları müdür yönetim tarzı ile mesleki motivasyon düzeyleri arasındaki ilişki, Uluslararası Sosyal ve Eğitim Bilimleri Dergisi, 5(10), 188-208.

Şakar, S. A. (2013). Ortaokul ve liselerde çalışan ingilizce ögretmenlerinin ögrretmen özerkliğine dair algıları: Sakarya ili örneği, (Yüksek Lisans Tezi), Onsekiz Mart Üniversitesi Eğitim Bilimleri Enstitüsü, Çanakkale.

Şentürken, C. (2018). Ortaöğretim öğretmenlerinin özerklik davranışları ile iş doyumları arasındaki ilişki, (Yayınlanmış Yüksek Lisans Tezi). Dumlupınar Üniversitesi Eğitim Bilimleri Enstitüsü, Kütahya.

Tedmem (2015). Öğretmen özerkliği ve okul özerkliği üzerine. https://tedmem.org/mem-notlari/degerlendirme/ogretmen-ozerkligi-ve-okulozerkligi-uzerine, (Erişim Tarihi: 21.10.2015). 
Terzi, A. R. \& Kurt, T. (2005). İlköğretim okulu müdürlerinin yöneticilik davranışlarının öğretmenlerin örgütsel bağlllığına etkisi, Milli Eğitim Dergisi, 33(166), 98-112.

Üstüner, M. (2016). Algılanan müdür yönetim tarzı ölçeğinin geçerlik ve güvenirlik çalışması. Kuram ve Uygulamada Eğitim Yönetimi, 22(3), 429-457.

Üzüm, P. (2014). Sinıf Öğretmenlerinin Öğretmen Özerkliğine İlişkin Farkındalık Düzeylerinin Yapısal ve Bireysel Boyutları Açısından Değerlendirilmesi (İzmir İli Örneği) (Doktora Tezi). Çanakkale Onsekiz Mart Üniversitesi Eğitim Bilimleri Enstitüsü, Çanakkale.

Üzüm, P. \& Karsl1, M. D. (2013). Sınıf öğretmenlerinin öğretmen özerkliğine ilişkin farkındalık düzeyleri, Inönü Üniversitesi Eğitim Fakültesi Dergisi, 14(3), 79-94.

Yıldırım, A., Ünal, A., \& Çelik, M. (2011). Öğretmen kavramına ilişkin öğretmen, yönetici ve müfettiş algılarının analizi. Uluslararası İnsan Bilimleri Dergisi, 8(2), 92-109. https://www.acarindex.com/dosyalar/makale/acarindex1423936367.pdf.

\section{ORCID}

Püren AKÇAY (D) https://orcid.org/0000-0002-0087-7561

Halid Hamza SEVINÇ ${ }^{(D)}$ https://orcid.org/0000-0003-1316-9182 


\section{SUMMARY}

\section{Purpose}

The aim of this study is to reveal the relationship between school administrators' management styles and teacher autonomy within the framework of various variables. In line with this main purpose, answers to the following questions were sought in this study: What are the perceived management styles of school administrators and the autonomy of teachers? Do school administrators 'perceived management styles and teachers' autonomy levels differ significantly according to gender, age, seniority, education level, management experience, branch and school type variable? Is there a relationship between school administrators 'perceived management styles and teachers' autonomy levels?

\section{Method}

In this research, relational scanning model, one of the quantitative research methods, was used. The sample of the study consists of 367 classroom teachers working in public primary schools in Adiyaman Province, Kâhta District. While selecting the sample, one of the purposeful sampling methods, the simple random sampling method was determined. Socio-demographic Information Form ',' Teacher Autonomy Scale 'and' Perceived Principal Management Style Scale 'were used as data collection tools in this study. In the present study, the Cronbach alpha reliability coefficient (0.936) obtained from the Teacher Autonomy Scale and the Cronbach alpha reliability coefficient (0.885) obtained from the Perceived Principal Management Style Scale in the present study show that the scale is a reliable tool in measuring the management styles of school administrators.

\section{Data Analysis}

The validity and reliability of the scales used in the study were measured with the help of the Cronbach Alpha coefficient. Reliability was found to be high in all sub-dimensions of the management skills scale and humor behavior scale and in all of both scales. Kurtosis and skewness values were taken as basis to control the normal distribution of the data. Considering these data, it was accepted that the distribution showed normality and it was decided to apply parametric tests in the analysis of the data obtained from the Teacher Autonomy Scale and the Perceived Principal Management Style Scales. Since the data of both scales to be used in the study showed normal distribution, the arithmetic mean and standard deviation values were taken into consideration from the descriptive statistics, and in the analysis of the data, the Independent $T$ Test was applied to the variables with two groups, and the One-Way Analysis of Variance (ANOVA) was applied to the variables with three or more groups. Finally, Pearson correlation analysis was used to determine the level of relationship between school principals' management styles and teacher autonomy levels.

\section{Conclusion and Discussion}

As a result, it is seen that if the management style exhibited by school administrators is appropriate, positive and based on cooperation, it contributes to the development and protection 
of teacher autonomy, and if it is negative, it causes the duty and responsibility of teachers to narrow. School administrators should involve teachers in management and decision-making processes, share their powers and responsibilities with them, and provide teachers with real autonomy for teaching as they want in the classroom. In line with the findings of the study, it is concluded that teachers should be given more right and responsibility to participate in school management. Teaching Profession Act in Turkey should be removed and the desired levels of teacher autonomy should be granted to teachers by this law. In addition, many secondary duties assigned to teachers should be abolished in order to protect teacher autonomy in our country. Even an important profession such as school administration is defined as a secondary task for teachers in regulations. Elimination of these problems with the regulations to be made in the legislation will provide a significant degree of autonomy for both administrators and teachers. It is thought that conducting new research on teacher autonomy by using different sample groups and different research methods and also investigating the relationship between the concept of teacher autonomy and other concepts in the literature will be beneficial for the literature. 
Ek 1. Etik Kurul Onay Belgesi

Evrak Tarih ve Sayısi: 17.03.2021-7798

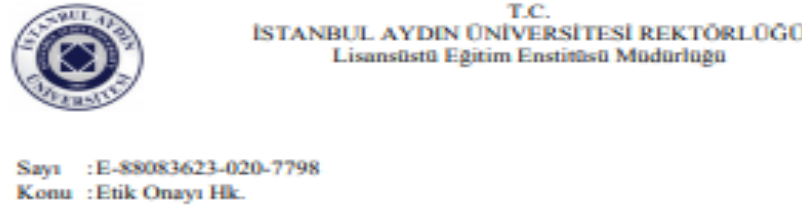

Dr.Ör.Oyesi Alper FiDAN

Mudur Yardumcisı

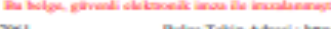


